\title{
Pesticide Usage: Attitudes and Practices among Rural Farmers in South India
}

\section{Gulappa Devagappanavar}

Guest Faculty, School of Environmental Science, Public Health and Sanitation Management, Karnataka State Rural Development and Panchayat Raj University, Gadag, India.

How to cite this paper: Gulappa Devagappanavar. (2021) Pesticide Usage: Attitudes and Practices among Rural Farmers in South India. International Journal of Clinical and Experimental Medicine Research, 5(3), 254-259. DOI: 10.26855/ijcemr.2021.07.004

Received: March 28, 2021

Accepted: April 26, 2021

Published: May 20, 2021

*Corresponding author: Gulappa Devagappanavar, Guest Faculty, School of Environmental Science, Public Health and Sanitation Management, Karnataka State Rural Development and Panchayat Raj University, Gadag, India. Email: gulappa.md07dmr@gmail.com

\begin{abstract}
Background: The major occupational diseases in India are occupational accidents, pneumoconiosis, musculoskeletal injuries, pesticide poisoning, and work place stress. Despite of low consumption of pesticides on global scale, cases of pesticide poising among Indian farmers are increasing every year. The reasons are many so in this study we wanted to assess the famers' attitudes and practices about pesticide usage in rural areas of north Karnataka. Methods: A field based cross sectional study was conducted in the rural areas of Karnataka state Gadag district. Farmer's, attitudes and practices about pesticide usage and its harmful effects on human health was assessed. A pre-tested semi-structured questionnaire was used to obtain the data from January to February 2020. Data were collected at the rural settings by visiting their house and agriculture fields. Results: Totally 265 farmers were interviewed, out of that Almost all of them have good attitudes about pesticide usage, impacts on environment and only $40 \%$ of them have good practices about the pesticide usage. Conclusion: Majority of the Farmers have good attitudes and practices about pesticide usage. Nearly more than half of the participants have poor practices in personal protective equipment's usage while spraying the pesticide.
\end{abstract}

\section{Keywords}

Attitudes and Practices, Farmers practices, PPE Usage, Pesticide usage, Occupational health

\section{Introduction}

Occupational health is defined as the highest degree of physical, mental and social well-being of workers in all occupations. It is the branch of healthcare which deals with all aspects of health and safety at the workplace. It lays strong emphasis on the prevention of hazards at a primary level.

Agriculture is the second largest sector in the world as a source of work force. In other respects, agriculture is one of the most dangerous occupations among all sectors in the world [1].

India, by virtue of its huge young population, is an important country not only in Asia but in the whole world. It has been slow to adopt the high standards of occupational health and safety. However, majority of Indian population was engaged in unorganized sector such as agriculture work and resides in rural area; though the urban population has been on rise [2].

Pesticides are widely used in agricultural production to prevent or control pests, diseases, weeds, and other plant pathogens in an effort to reduce or eliminate yield losses and maintain high product quality [3].

Pesticide use in most Indian agriculture is an essential part of production technology and agriculture is an impor- 
tant sector for economic development in India [4].

Lack of education, lack of knowledge, and unintentional application errors such as handling of pesticides carelessly can pose serious health risks to farmers. Their knowledge, attitudes and practices on potential hazards of pesticide is very important in preventing pesticide exposure [5].

India urgently requires modern Occupational Health Safety (OHS) legislation with adequate enforcement machinery, and establishment of centers of excellence in occupational medicine, to catch up with the rest of the world [6]. So in this study we have assessed the farmer's attitudes and practices regarding pesticide usage in South India.

\section{Materials and Methods}

\subsection{Study setting}

A field based cross sectional study was conducted in the rural areas of Gadag district on farmers. Data were obtained from January to February 2020; a pre-tested semi-structured interview questionnaire was used.

\subsection{Study design}

Purposive sampling technique was used to recruit the study participants. Socio-demographic details, attitudes and practices about the pesticide usage and its harmful effects on farmers health related data were obtained.

\subsection{Participants}

Those who involved in the agriculture activity and have experienced of previously used the pesticides and have at least once sprayed the pesticide. Among them those who given oral consent to participate in the study were included.

\subsection{Variables}

Independent variables: Gender, age, education and income status.

Dependent variables: Attitude and practice related Pesticide usage.

\subsection{Data sources}

Primary data were obtained introducing the questionnaire to farmers, visited the farmer's agriculture fields to obtain the data. Attitude and practice were assessed related to pesticide usage and its harmful effects on their health.

\subsection{Study size}

Purposive sampling technique method was used to recruit the study participants. Totally 265 farmers data were collected from the 5 villages.

\subsection{Statistical methods}

Data were entered into excel sheet, analyzed using SPSS v20 and expressed in frequency and percentages. Findings were expressed Descriptive statistics.

\section{Results}

In the current study, majority of the participants are belongs to 41-50 age group, half of them are completed primary education and all most all are married (Table 1).

In our findings, most of the farmers are agreed that pesticides are affects the human health and environment. Only few and majority of the farmers are neutral about the combination of pesticides more effective and safe usage was everyone's responsibility respectively. Nearly $1 / 3^{\text {rd }}$ of the farmers are agreed that proper disposal of pesticide will reduce the environmental risk and it should store separately and handled safely. Most of them agreed that usage of personal protective equipment would reduce the risk on human health (see Table 2).

In the present study, more than half of the farmers have good practices about pesticide procurement, pest control advice and storage. Only few farmers have poor practices about empty pesticide bottles and unused leftover pesticides. More than half of the famers have the practice of wearing the mask which covers Nose and mouth. Very interesting finding was only one farmer responded that he will wore all personal protective equipment's while spraying the pesticide (Table 3). 
Table 1. Socio-demographic details of study participants

\begin{tabular}{|c|c|c|}
\hline \multicolumn{2}{|c|}{ Characteristics } & \multirow{2}{*}{$\begin{array}{c}\text { Frequency (\%) } \\
232(87.5)\end{array}$} \\
\hline Conder & Male & \\
\hline Genduer & Female & 33 (12.5) \\
\hline \multirow{5}{*}{ Age Group } & $20-30$ & $17(06.4)$ \\
\hline & $31-40$ & 82 (30.9) \\
\hline & $41-50$ & 89 (33.6) \\
\hline & $51-60$ & $56(21.1)$ \\
\hline & 61 \& Above & 21 (07.9) \\
\hline \multirow{5}{*}{ Education level } & Illiterate & 57 (21.5) \\
\hline & Primary & 113 (42.6) \\
\hline & Secondary & 74 (27.9) \\
\hline & Undergraduate & 13 (04.9) \\
\hline & Graduate & 08 (03.0) \\
\hline \multirow{2}{*}{ Marital status } & Single & 10 (03.8) \\
\hline & Married & 255 (96.2) \\
\hline
\end{tabular}

Table 2. Farmers' attitudes about pesticide usage (n-265)

\begin{tabular}{|c|c|c|c|c|c|}
\hline Variables & Agree & $\begin{array}{c}\text { Strongly } \\
\text { agree }\end{array}$ & Disagree & $\begin{array}{l}\text { Strongly } \\
\text { disagree }\end{array}$ & Neutral \\
\hline Pesticides affect human health & $236(89.1)$ & $16(6.0)$ & $10(03.8)$ & 00 & $03(01.1)$ \\
\hline Pesticides affect the Environment & $221(83.4)$ & $11(4.2)$ & $24(09.1)$ & $01(00.4)$ & $08(03.0)$ \\
\hline Usage of Combination pesticides more effective & $217(81.9)$ & $02(0.8)$ & $17(06.4)$ & 00 & $29(10.9)$ \\
\hline Safe usage of pesticide is everyone's responsibility & $227(85.7)$ & $11(04.2)$ & $04(01.5)$ & 00 & $23(08.7)$ \\
\hline $\begin{array}{c}\text { Proper disposal pesticide and containers will reduce the } \\
\text { environmental risk }\end{array}$ & $232(87.5)$ & $09(03.4)$ & $04(01.5)$ & 00 & $20(07.5)$ \\
\hline Pesticides should store Separately and handled safely & $245(92.5)$ & $11(04.2)$ & $03(01.1)$ & $01(00.4)$ & 05 (01.9) \\
\hline $\begin{array}{l}\text { Usage of Personal Protective Equipment's reduce the risk } \\
\text { on human health }\end{array}$ & $229(86.4)$ & 07 (02.6) & $11(04.2)$ & $02(00.8)$ & $16(06.0)$ \\
\hline
\end{tabular}

Table 3. Farmers' common practices about pesticide procurement and storage

\begin{tabular}{|c|c|c|c|}
\hline \multirow{2}{*}{ Questions } & \multicolumn{3}{|c|}{ Responses (n-265) } \\
\hline & Options & Frequency & Percentage \\
\hline \multirow{2}{*}{ Where do you procure the pesticides } & Licensed shop & 238 & 89.8 \\
\hline & Others & 27 & 10.2 \\
\hline \multirow{3}{*}{ Where do you get the pest control advice } & Pesticide sales agent & 194 & 73.2 \\
\hline & Others & 71 & 28.6 \\
\hline & In home & 53 & 20.0 \\
\hline \multirow[t]{2}{*}{ Where do you store pesticides } & In Farm house & 59 & 22.3 \\
\hline & In Separate cupboard & 153 & 57.7 \\
\hline \multirow{4}{*}{$\begin{array}{l}\text { What do you do with the empty } \\
\text { pesticide cans or bottles }\end{array}$} & Discarded & 144 & 43.0 \\
\hline & Washed and Reuse & 90 & 34.0 \\
\hline & Burnt & 61 & 23.0 \\
\hline & Discarded & 106 & 40.0 \\
\hline \multirow[t]{5}{*}{ What do you with the unused leftover Pesticides } & Stored and Reused & 125 & 47.2 \\
\hline & Bury in Soil & 34 & 12.8 \\
\hline & Gloves & 27 & 10.2 \\
\hline & Goggles & 05 & 01.9 \\
\hline & Full sleeved shirts & 35 & 13.2 \\
\hline \multirow[t]{4}{*}{$\begin{array}{l}\text { Which of the following do you wear while spraying } \\
\text { the of Pesticides }\end{array}$} & $\begin{array}{l}\text { Mask covering the Nose and } \\
\text { Mouth }\end{array}$ & 154 & 58.1 \\
\hline & Full shoes & 00 & 00 \\
\hline & All of the above & 01 & 00.4 \\
\hline & None of the above & 43 & 16.2 \\
\hline
\end{tabular}


Table 4. Farmers' safety practices about pesticide usage

\begin{tabular}{cccc}
\hline \multicolumn{1}{c}{ Variables } & \multicolumn{3}{c}{ Response by the farmers (n-265) } \\
& Always & Sometimes & Never \\
\hline Consumption of the food while mixing or spraying the pesticides & $53(20)$ & $44(16.6)$ & $168(63.4)$ \\
Drinking water while mixing or spraying the pesticides & $20(07.5)$ & $41(15.5)$ & $204(77.0)$ \\
Smoking while mixing or spraying the pesticides & $16(06.0)$ & $45(17.0)$ & $204(77.0)$ \\
Pesticide sprayed in the direction of wind & $112(42.3)$ & $84(31.7)$ & $69(26.0)$ \\
Showering immediately after mixing or spraying & $122(46.0)$ & $98(37.0)$ & $45(17.0)$ \\
Washing of wearied clothes separately & $167(63.0)$ & $82(31.0)$ & $16(06.0)$ \\
\hline
\end{tabular}

In this study, we came out with an interesting findings about safety practices, more than half the farmers never done the mixing or spraying of the pesticides while consuming food, drinking water and smoking. Nearly half of the farmers have practice of sprayed pesticide in the direction of wind, showering immediately after mixing or spraying and washed their clothes separately (Table 4).

\section{Discussion}

\subsection{Study population}

In the current study, majority of the famers are male and belongs to the age group to 41-50 years, have completed primary education and married.

\subsection{Attitudes about pesticide usage}

In the findings, majority of the farmers have agreed that pesticide and its usage will affect the human health and environment. A study conducted in Turkey, Palestine, Uganda and Brazil found the same findings [7-10].

Majority of the participants are agreed that safe disposal of pesticide containers will reduce the health risk and environmental risk. Similar findings have been found in the study conducted at Pondicherry [11], Nepal [12], Tanzania [13].

In this study, all most all farmers are agreed that pesticide should be stored separately and handled safely. Similar opinion has been found in the study conducted at West-Bengal [14] and Bangladesh [15]. But a study conducted at Pakistan found unsafe storage of pesticides [16].

Nearly $1 / 3^{\text {rd }}$ of the study participants was agreed to usage of PPE will reduce the risk on human health. Same results have been found in Ethiopia [17] and Kuwait [18].

\subsection{Common Practices}

In the current study, majority of the famers have practice of purchasing pesticide from licensed shop. The similar findings have been found in Nigeria [19] and contradictory result has been found in Ethiopia [20].

In our findings, only few farmers will burn the pesticide containers. The similar opinion has been found in World Health Organization report [21].

More than half of the famers stored the pesticide bottles in the safest place. A study conducted at France found the same findings [22] and in Bahrain [23].

Only few famers have the practice of wearing the gloves while spraying the pesticide. The similar findings found in Madhya Pradesh study [24], but a study conducted in Ethiopia found that majority of the farmers wore gloves [17].

More than half of the study participants have the practice of wearing mask. A similar result has been found in the study conducted in Indonesia [25].

\subsection{Safety Practices}

In our findings, more than half of the farmers have never consumed food while praying or mixing the pesticide. Similar findings have been found in Greece [3] and a contradictory result has been found in the study conducted in West Bengal [14].

Nearly $1 / 3^{\text {rd }}$ of the farmers have never drank the water while spraying the pesticide. A similar finding has been found in Ghana [26], Ethiopia [27] and in Australia [28]. 
Nearly half of the farmers have the practice of showering and washing their clothes separately. Similar results have been found in the study conducted at Turkey [29] and in Iran [30].

\section{Conclusion}

Famers have good attitudes and practices about the pesticide usage but they were not wearing the personal protective equipment's. They have adopted the good practices regarding food consumption, drinking of water and showering after the pesticide sprayed.

\section{Acknowledgement}

I would like to acknowledge all Master of Public Health Scholars and Karnataka State Rural Development and Panchayat Raj University, Gadag, Prof. Vishnukant S Chatpalli Vice Chancellor and Prof. B. L. Lakkannavar Registrar, Honorary Professor Dr. Suresh Kishanrao for their support and guidance.

\section{Ethical Approval}

KSRDPRU Institutional ethics committee.

\section{References}

[1] Mahmoud, S., Seyed, H., Hosseini, M. (2012). Farmers’ perceptions of safe use of pesticides: determinants and training needs. 2012; 57-66.

[2] Pingle, S. (2012). Occupational Safety and Health in India: Now and the Future. 2012; 167-71.

[3] Damalas, C. A., Eleftherohorinos, I. G. (2011). Pesticide exposure, safety issues, and risk assessment indicators. Int J Environ Res Public Health. 2011; 8(5): 1402-19.

[4] Shetty, P. K., Murugan, M., Hiremath, M. B., Sreeja, K. G. (2010). Farmers' education and perception on pesticide use and crop economies in Indian agriculture. J Exp Sci. 2010; 1(October 2014): 3-08.

[5] Pesticide use and safety practices among Greek tobacco farmers_ A survey_ International Journal of Environmental Health Research_Vol. 16, No. 5.

[6] Agnihotram, R. V. (2005). An overview of occupational health research in India. Indian J Occup Environ Med., 2005; 9(1): 10-4.

[7] G DÖ, Kurt, B., Koç, A. G., Akbaba, M., Hüseyin, E. (2018). Knowledge Level, Attitude, and Behaviors of Farmers in Çukurova Region regarding the Use of Pesticides. 2018.

[8] Yassin, M. M., Abu Mourad, T. A., Safi, J. M. (2002). Knowledge, attitude, practice, and toxicity symptoms associated with pesticide use among farm workers in the Gaza Strip. Occup Environ Med., 2002; 59(6): 387-93.

[9] Oesterlund, A. H., Thomsen, J. F., Sekimpi, D. K., Maziina, J., Racheal, A., Jørs, E. (2014). Pesticide knowledge, practice and attitude and how it affects the health of small-scale farmers in Uganda: A cross-sectional study. Afr Health Sci. 2014; 14(2): 420-33.

[10] Pasiani, J. O., Torres, P., Silva, J. R., Diniz, B. Z., Caldas, E. D. (2012). Knowledge, attitudes, practices and biomonitoring of farmers and residents exposed to pesticides in Brazil. Int J Environ Res Public Health. 2012; 9(9): 3051-68.

[11] Mohanty, M. K., Behera, B. K., Jena, S. K., Srikanth, S., Mogane, C., Samal, S., et al. (2013). Knowledge attitude and practice of pesticide use among agricultural workers in Puducherry, South India. Journal of Forensic and Legal Medicine. 2013. Vol. 20, 1028-31.

[12] Gyawali, K. (2018). Pesticide Uses and Its Effects on Public Health and Environment. J Heal Promot. 2018; 6(June): $28-36$.

[13] Lekei, E. E., Ngowi, A. V., London, L. (2014). Farmers' knowledge, practices and injuries associated with pesticide exposure in rural farming villages in Tanzania. BMC Public Health. 2014; 14(1): 1-13.

[14] Das, D. K., Dey, T. K. (2005). Agricultural practices and personal hygiene among agricultural workers in a rural area of Howrah district, West Bengal. Indian J Public Health. 2005; 49(4): 252-3.

[15] Shammi, M., Sultana, A., Hasan, N., Mostafizur Rahman, M., Saiful Islam, M., Bodrud-Doza, M., et al. (2020). Pesticide exposures towards health and environmental hazard in Bangladesh: A case study on farmers' perception. J Saudi Soc Agric Sci [Internet]. 2020; 19(2): 161-73. Available from: https://doi.org/10.1016/j.jssas.2018.08.005.

[16] Mubushar, M., Aldosari, F. O., Baig, M. B., Alotaibi, B. M., Khan, A. Q. (2019). Assessment of farmers on their knowledge regarding pesticide usage and biosafety. Saudi J Biol Sci [Internet]. 2019; 26(7): 1903-10. Available from: https://doi.org/10.1016/j.sjbs.2019.03.001.

[17] Gesesew, H. A., Woldemichael, K., Massa, D., Mwanri, L. (2016). Farmers knowledge, attitudes, practices and health problems associated with pesticide use in rural irrigation villages, Southwest Ethiopia. PLoS One. 2016; 11(9): 1-13. 
[18] Jallow, M. F. A., Awadh, D. G., Albaho, M. S., Devi, V. Y., Thomas, B. M. (2017). Pesticide knowledge and safety practices among farm workers in Kuwait: Results of a survey. Int J Environ Res Public Health. 2017; 14(4).

[19] Irenonsen, U. O., Igbokwe, E. M., Enwelu, I. A. (2015). Knowledge and Practices of Herbicide Use Among Farmers in Edo State, Nigeria. Int J Soc Relev Concern. 2015; 3(4): 1-8.

[20] Negatu, B., Kromhout, H., Mekonnen, Y., Vermeulen, R. (2016). Use of chemical pesticides in Ethiopia: A cross-sectional comparative study on knowledge, attitude and practice of farmers and farm workers in three farming systems. Ann Occup Hyg. 2016; 60(5): 551-66.

[21] WHO. Guidelines on the prevention of toxic exposures-Education and public awareness activities [Internet]. International Programme on Chemical Safety. 2004. Available from: http://www.who.int/ipcs/features/prevention_guidelines.pdf.

[22] Salameh, P. R., Baldi, I., Brochard, P., Abi Saleh, B. (2004). Pesticides in Lebanon: A knowledge, attitude, and practice study. Environ Res. 2004; 94(1): 1-6.

[23] Al-Haddad, S. A. (2013). Bahrain Medical Bulletin, Vol. 35, No. 1, March 2013. October. 2013; 35(1): 1-6.

[24] Choudhary, A. (2014). Adverse Health Effects of Organophosphate Pesticides among Occupationally Exposed Farm Sprayers: A Case Study of Bhopal Madhya Pradesh, India. Asian J Biomed Pharm Sci. 2014; 4(35): 30-5.

[25] Yuantari, M. G. C., Van Gestel, C. A. M., Van Straalen, N. M., Widianarko, B., Sunoko, H. R., Shobib, M. N. (2015). Knowledge, attitude, and practice of Indonesian farmers regarding the use of personal protective equipment against pesticide exposure. Environ Monit Assess. 2015; 187(3).

[26] Abdulahi, A., Obiri-danso, K., Mohammed, S. (2015). Effect of farmers' attitude, usage pattern and handling of pesticides on potable water quality in northern Ghana. Int J Dev Sustanable. 2015; 4(10): 977-87.

[27] Karunamoorthi, K., Mohammed, A., Jemal, Z. (2011). Peasant association member's knowledge, attitudes, and practices towards safe use of pesticide management. American Journal of Industrial Medicine. 2011. Vol. 54, pp. 965-70.

[28] Duong, T. T., Luck, J., Zander, K. K. (2019). Understanding the intention to use biosecurity management strategies on-farm: A study of Vietnamese farmers in Australia. Social Science Journal. 2019.

[29] Derafshi, M., Black, C., Agnew, R. (2017). Pesticide Knowledge, Attitudes, and Clothing Practices of Turkish Farmers. Environ Manag Sustain Dev. 2017; 6(1): 149.

[30] Sharifzadeh, M. S., Abdollahzadeh, G., Damalas, C. A., Rezaei, R., Ahmadyousefi, M. (2019). Determinants of pesticide safety behavior among Iranian rice farmers. Sci Total Environ. 2019; 651: 2953-60. 